\title{
Potensi Ampas Kelapa untuk Meningkatkan Pendapatan Petani di Kabupaten Manokwari Papua Barat
}

Rinjani Alam Pratiwi ${ }^{1 *}$, Arya Bima Senna ${ }^{2}$

${ }^{1}$ Balai Pengkajian Teknologi Pertanian Papua Barat

${ }^{2}$ Balai Pengkajian Teknologi Pertanian Papua Barat

\begin{tabular}{l}
\multicolumn{1}{c}{ ARTIKEL INFO } \\
\hline Sejarah artikel \\
Diterima $12 / 10 / 2021$ \\
Diterima dalam bentuk revisi 20/12/2021 \\
Diterima dan disetujui 24/12/2021 \\
Tersedia online 31/12/2021 \\
\hline Kata kunci \\
Ampas kelapa \\
Kukis kelapa \\
Pendapatan petani \\
Tepung kelapa \\
\hline
\end{tabular}

\begin{abstract}
ABSTRAK
Kabupaten Manokwari memiliki banyak potensi apabila dilihat dari sumber daya alamnya. Salah satunya adalah potensi tanaman perkebunan yang dapat dikembangkan dengan tepat sasaran. Menurut data tahun 2018 ke 2019 terdapat penurunan luas lahan tanaman kelapa sebesar 38 ha. Namun demikian untuk jumlah produksi kelapa mengalami peningkatan yang cukup tinggi yakni 55.568 ton atau sebesar 62 kali lipat dari produksi tahun sebelumnya. Tanaman kelapa merupakan tanaman mempunyai beragam manfaat bagi manusia karena hampir semua bagian dari tanaman kelapa bisa dimanfaatkan mulai dari produk makanan, minuman, kesehatan hingga kecantikan. Daging buah kelapa biasanya hanya diambil santannya, sedangkan ampas dari kelapa tersebut menjadi limbah dan dibuang begitu saja atau dijadikan sebagai pakan ternak. Tidak banyak orang yang mengetahui bahwa ampas kelapa dapat dijadikan sebagai tepung. Tepung kelapa diperoleh dari proses pengeringan ampas kelapa yang kemudian dihaluskan hingga menjadi tepung yang mempunyai nilai jual. Hal ini dapat dijadikan alternatif untuk membuat olahan makanan salah satunya adalah kukis. Pengolahan kukis ampas kelapa memerlukan 300 gram tepung kelapa, 300 gram tepung terigu, 300 gram margarin, 3 butir telur, 300 gram gula halus, 6 sendok makan tepung maizena, 1,5 sendok teh soda kue dan chocochip sesuai selera dengan jumlah modal yang dikeluarkan sebesar Rp 73.500 dan menghasilkan kukis dengan berat bersih 1,2 kg. Harga jual kukis per kemasan 200 gram adalah $\mathrm{Rp} 60.000$, sehingga total pendapatan petani senilai $\mathrm{Rp} 360.000$. Keuntungan yang dapat diperoleh petani Rp 286.500.
\end{abstract}

(C) 2021 Politeknik Pembangunan Pertanian Manokwari 


\section{ABSTRACT}

Manokwari Regency has a lot of potential when viewed from its natural resources. One of them is the potential of plantation crops that can be developed on target. According to data from 2018 to 2019, there was a decrease in the area of coconut plantations by $38 \mathrm{ha}$. However, the amount of coconut production experienced a fairly high increase, namely 55.568 tons or 62 times the production of the previous year. The coconut plant is a plant that has various benefits for humans because almost all parts of the coconut plant can be used, ranging from food products, beverages, health to beauty. The coconut flesh is usually only taken with the coconut milk, while the pulp from the coconut becomes waste and is thrown away or used as animal feed. Not many people know that coconut

\section{PENDAHULUAN}

Kabupaten Manokwari merupakan salah satu kabupaten yang terletak di Provinsi Papua Barat dengan keanekaragaman hayati yang sangat beragam, hal tersebut ditunjang karena ketersediaan sumber daya alam yang melimpah. Potensi alam yang ada mulai dari wisata, kelautan, pertanian hingga perkebunan. Semua sektor-sektor tersebut masih harus dikembangkan dengan optimal. Dilihat dari letaknya Kabupaten Manokwari memang memiliki potensi dalam pengembangan tanaman perkebunan, salah satu yang banyak dijumpai di area tempat tinggal penduduk lokal adalah tanaman kelapa.

Tanaman kelapa merupakan tanaman mempunyai beragam manfaat bagi manusia. Hampir semua bagian dari tanaman kelapa bisa dimanfaatkan. Mulai dari batangnya yang dapat dimanfaatkan sebagai bahan bangunan hingga daunnya bisa juga dijadikan sebagai kerajinan tangan. Disisi lain, hingga saat ini bagian buah kelapa mempunyai sisi ekonomi paling tinggi pulp can be used as flour. Coconut flour is obtained from the drying process of coconut pulp which is then mashed to become flour that has a selling value. This can be used as an alternative to make processed foods, one of which is cookies. Processing of coconut dregs cookies requires 300 grams of coconut flour, 300 grams of flour, 300 grams of margarine, 3 eggs, 300 grams of refined sugar, 6 tablespoons of cornstarch, 1,5 teaspoons of baking soda and chocochips according to taste with the amount of capital spent of $R p$ 73,500 and produce cookies with a net weight of $1,2 \mathrm{~kg}$. The selling price of cookies per pack of 200 grams is $R p 60.000$, so that the total income of farmers is $R p$ 360.000. The profit that can be obtained by farmers is $R p 286.500$.

diantara bagian tanaman kelapa yang lain. Buah kelapa dapat dimanfaatkan menjadi beberapa produk makanan, minuman, kesehatan hingga kecantikan. Dalam kehidupan sehari-hari, daging buah kelapa biasanya hanya diambil santannya saja untuk diolah sesuai dengan kebutuhan. Ampas dari kelapa tersebut menjadi limbah dan dibuang begitu saja atau dijadikan sebagai pakan ternak. Belum banyak orang yang memanfaatkan ampas kelapa secara optimal karena dianggap ampas kelapa tidak memiliki nilai ekonomi.

Tidak banyak orang yang mengetahui bahwa ampas kelapa dapat dijadikan sebagai tepung. Tepung kelapa dapat diolah menjadi makanan yang mempunyai nilai jual. Tepung kelapa diperoleh dari proses pengeringan ampas kelapa yang kemudian dihaluskan hingga menjadi tepung. Menurut Putri (2014) kadar air tepung tepung ampas kelapa lebih rendah dari pada pada kadar air tepung terigu. Sehingga dengan kadar air yang rendah tersebut 
berpengaruh terhadap umur simpan tepung yang lebih lama.

Produksi tepung kelapa juga dinilai sangat ekonomis karena tepung tersebut dapat diproduksi dalam skala kecil maupun skala yang besar. Bahan baku yang berupa limbah sangat mudah didapatkan. Proses pengolahan menjadi tepung mudah dilakukan dengan menggunakan peralatan sederhana dan murah. Tepung kelapa sebagai sumber serat makanan yang baik dapat ditambahkan ke produk roti, resep dan produk makanan lainnya untuk kesehatan yang baik. Tepung kelapa juga mempunyai fungsi untuk pencegahan risiko beberapa penyakit kronis, yakni diabetes mellitus, kardiovaskular, dan kanker usus besar (Trinidad et al., 2006).

Tepung kelapa bisa dijadikan alternatif untuk membuat olahan makanan salah satunya adalah kukis. Kukis merupakan kue kering yang mempunyai nilai jual dan juga banyak penggemar. Kukis biasanya berbahan dasar tepung terigu, tetapi dengan penambahan tepung kelapa dalam adonannya dapat memberikan rasa yang sedikit berbeda dari kukis pada umumnya. Aroma khas tepung kelapa juga dapat menjadi daya tarik tersendiri dari kukis kelapa tersebut.

Pemanfaatan limbah ampas kelapa untuk diolah menjadi kukis kelapa mempunyai nilai tambah dari segi ekonomi. Pendapatan petani juga akan meningkat apabila petani diberikan pengetahuan mengenai optimalisasi pemanfaatan limbah tersebut. Petani kelapa biasanya hanya menjual kelapa tua kepada pengepul dengan harga yang relatif rendah. Oleh sebab itu, sangat penting untuk memberikan informasi kepada petani mengenai optimalisasi pengolahan kelapa menjadi berbagai macam produk yang mempunyai nilai jual lebih tinggi. Tulisan ini merupakan hasil telaah pustaka yang bertujuan memaparkan potensi limbah dari ampas kelapa sebagai peningkatan pendapatan petani di Kabupaten Manokwari.

\section{KELAPA}

Kelapa merupakan tanaman yang banyak tumbuh di negara tropis, untuk di Indonesia sendiri kelapa merupakan salah satu tanaman yang sudah masuk ke aspek ekonomi maupun budaya dari dijual hingga hingga masuk ke industri selain banyak tanaman tahunan lain karena jumlah yang banyak tumbuh dan mudah beradaptasi di daerah-daerah. Terlihat dari jumlah perkebunan kelapa di Indonesia merupakan yang terluas di dunia dengan luasan mencapai 3.712 Juta Ha. Sedangkan produksi kelapa mencapai 12.915 miliar butir $(24,4 \%$ produksi dunia) dan menempati posisi kedua di dunia (Alamsyah, 2005).

Kelapa menjadi salah satu komoditas yang memiliki nilai ekonomis tinggi di perdagangan dunia karena mengingat kelapa dibutuhkan di berbagai sektor industri, Indonesia merupakan salah satu penghasil kelapa yang utama di dunia (Sukamto, 2001) komoditas ini bersaing ketat dengan kelapa sawit. Kelapa memiliki banyak hasil yang diambil dari segi ekonomi dan industri melalui minuman segar, santan, kelapa parut kering, gula kelapa, kue kelapa yang merupakan Produk pangannya. Sedangkan untuk produk yang non pangan antara lain serabut kelapa, 
arak aktif, dan masih banyak kerajinan tangan yang bisa dibuat (Saluki, 2018)

Kelapa merupakan tanaman tahunan, memiliki batang yang keras dan pada umumnya tidak bercabang (monopodial) dan berakar serabut. Pertumbuhan kelapa tegak ke atas tapi untuk bagian tertentu cenderung miring karena mengikuti sinar dari matahari (Mardiatmoko, 2018). Kelapa adalah tanaman yang dapat dijadikan sebagai sumber minyak, serat, susu, dan air pada sebagian besar wilayah tropis. Keberlanjutan perkebunan kelapa juga dapat dipengaruhi oleh berbagai komponen abiotik, termasuk kekeringan, nutrisi mineral, dan salinitas (Santos et al., 2020).

Daging buah kelapa yang bisa dimakan secara langsung tetapi juga dapat diolah menjadi beraneka ragam produk yang dapat memberikan nilai tambah secara ekonomi antara lain minyak kelapa, tepung kelapa, manisan, kelapa panggang dan sebagainya. Sedangkan untuk pengolahan minyak kelapa sendiri menghasilkan residu yaitu berupa ampas kelapa. Selama ini pemanfaatan ampas kelapa biasanya digunakan untuk pakan ternak karena dianggap sebagai produk yang tidak memiliki nilai ekonomis. Padahal, ampas kelapa mengandung karbohidrat, protein, rendah lemak, dan kaya serat, sehingga akan sangat bermanfaat bagi tubuh manusia (Yulvianti, 2015).

\section{Kandungan Gizi Tepung Kelapa}

Tepung kelapa merupakan tepung yang berasal dari limbah kelapa yang dihasilkan selama pemrosesan basah kelapa untuk ekstraksi susu atau pemrosesan kering untuk ekstraksi minyak. Tepung kelapa tidak hanya memiliki kandungan serat yang tinggi, tetapi tepung kelapa juga bebas dari asam trans-lemak dan rendah karbohidrat. Tepung kelapa tidak mengandung gluten sehingga cocok untuk individu yang mempunyai penyakit seliaka (Adeloye et al., 2020). Pembuatan ampas kelapa menjadi tepung kelapa memiliki proses pembuatan yang cenderung mudah sehingga bisa diterakpan ke usaha dengan skala yang kecil dan menengah. Proses pembuatan ini dapat dijadikan produsen kelapa untuk menambahkan nilai secara ekonomis sehingga ampas tidak terbuang secara cuma-cuma dan produsen mendapatkan tambahan pendapatan (Yulvianti, 2015)

Salah satu parameter yang menentukan nilai gizi pangan adalah jumlah dan macam zat gizi yang terdapat dalam pangan. Tepung kelapa mempunyai kandungan karbohidrat, lemak dan protein. Kadar karbohidrat tepung ampas kelapa lebih rendah $(33,64125 \%)$ dari tepung terigu yaitu $73,52 \%$ dan kadar protein tepung ampas kelapa ini cukup rendah $(5,78725 \%)$ dari pada tepung terigu $(13,5 \%)$, sehingga tepung ampas kelapa bukan merupakan pangan sumber protein, karena kandungan proteinnya yang sangat rendah. Namun demikian, kadar lemak tepung ampas kelapa $(38,2377 \%)$ lebih tinggi dari pada kadar lemak tepung terigu (1,07\%). Tepung dengan kadar lemak yang tinggi berpotensi sebagai pangan sumber lemak nabati yang memiliki efek positif pada kesehatan, apalagi jika diketahui jenis asam lemak yang ada dalam tepung ampas kelapa tersebut (Putri, 2014).

Tepung kelapa mengandung selulosa cukup tinggi yang mempunyai peran dalam 
proses fisiologi tubuh. Selulosa adalah serat makanan yang tidak dapat dicerna oleh enzimenzim pencernaan, namun peranannya dalam sistem pencernaan sangat penting, karena dapat mempersingkat waktu transit sisa-sisa makanan, sehingga mengurangi resiko kanker usus (Polii, 2017). Dewasa ini, kecenderungan manusia untuk mengkonsumsi makanan yang mengandung karbohidrat tinggi dan kurang serat menyebabkan ketidakseimbangan dalam tubuh seperti obesitas dan juga sulit buang air besar. Oleh karena itu, penting untuk mencari alternatif dalam menggunakan tepung yang mengandung serat sebagai bahan baku olahan makanan (Kumolontang, 2014).

\section{Pendapatan Petani}

Pendapatan adalah hasil dari penjualan faktor-faktor produksi yang dimilikinya kepada sektor produksi. Pendapatan adalah hasil berupa uang atau materi lainnya yang dapat dicapai dari pada penggunaan faktor-faktor produksi (Kuncoro, 2004). Menurut Samuelson dan Nordhaus (2005) dalam ilmu ekonomi pendapatan adalah hasil berupa uang maupun hal materi yang dapat dicapai dengan menggunaan barang produksi atau jasa yang ditawarkan oleh produsen barang atau jasa. Pendapatan rumah tangga adalah sejumlah uang dari hasil seluruh anggota keluarga yang diperoleh dari gaji maupun hasil dari industri rumah tangga. Jumlah pendapatan dapat diukur erdasarkan konsep jumlah uang yang diterima oleh seseorang dalam jangka waktu tertentu biasanya dalam waktu satu bulan.

Selisih antara penerimaan dan semua biaya meliputi pendapatan kotor dan pendapatan bersih disebut pendapatan usahatani. Sedangkan, pendapatan kotor merupakan nilai produksi komoditas pertanian secara menyeluruh sebelum dikurangi dengan biaya produksi (Abas, 2019). Pendapatan rumah tangga akan mempengaruhi kesejahteraan keluarga secara ekonomi. Sehingga pendapatan yang bertambah dapat membantu memenuhi kebutuhan keluarga, sedangkan apabila pendapatan rumah tangga yang kecil akan terbatasnya pemenuhan pendapatan keluarga (Nugraha, 2019).

\section{Potensi Kelapa di Kabupaten Manokwari}

Pemanfaatan lahan di sejumlah distrik di Kabupaten Manokwari menunjukkan bahwa wilayah kebanyakan dipenuhi penggunaan lahan pertanian dan hutan sebagai pemenuh kebutuhan, lahan pemukiman, perkebunan kelapa sawit dan areal semak belukar yang menyebabkan biokapasitas (Marwa et al., 2020). Kabupaten Manokwari memiliki banyak potensi apabila dilihat dari sumber daya alamnya. Potensi-potensi yang ada banyak yang belum dikembangkan dengan optimal. Salah satunya adalah potensi tanaman perkebunan yang dapat dikembangkan dengan tepat sasaran.

Perkembangan sejumlah komoditas menjadi tolok ukur meningkatnya perekonomian rakyat dalam hal ini ada kakao, pala, kelapa, dan ternak sapi. Khusus untuk pengembangan komoditas kelapa dan pala memerlukan perhatian kususnya dibidang pemasaran dikarenakan komoditas ini hanya berdampak kecil bagi pendapatan rumah tangga dikarenakan harga jual yang rendah. Walaupun kelapa banyak tersebar di lahan yang cukup luas dan hasil dari panennya banyak namun harga jualnya relatif rendah dan penggunanya paling 
banyak dari pasar lokal dikarenakan belum banyak petani yang melakukan pengolahan pasca panen secara baik (Supriadi, 2008).

Kabupaten Manokwari merupakan salah satu kabupaten di Provinsi Papua Barat yang semua distrik mempunyai lahan dan produksi kelapa. Menurut data yang dirilis Badan Pusat
Statistik (BPS) Kabupaten Manokwari 2020, dari tahun 2018 ke 2019 terdapat penurunan luas lahan tanaman kelapa sebesar 38 ha. Sedangkan untuk jumlah produksi kelapa mengalami peningkatan yang cukup tinggi yakni 55.568 ton atau sebesar 62 kali lipat dari produksi tahun sebelumnya.

Tabel 1. Luas Areal dan Produksi Tanaman Kelapa Kabupaten Manokwari

\begin{tabular}{llrrrr}
\hline \multirow{2}{*}{ No } & \multirow{2}{*}{ Kecamatan / Distrik } & \multicolumn{2}{c}{ Produksi Kelapa (ton) } & \multicolumn{2}{c}{ Luas Areal (ha) } \\
\cline { 3 - 6 } & & $\mathbf{2 0 1 8}$ & $\mathbf{2 0 1 9}$ & $\mathbf{2 0 1 8}$ & $\mathbf{2 0 1 9}$ \\
\hline 1 & Warmare & 0,2 & 3.359 & 0 & 6 \\
2 & Prafi & 0 & 40 & 0 & 325 \\
3 & Manokwari Barat & 40 & 95 & 128 & 235 \\
4 & Manokwari Timur & 180 & 3.077 & 495 & 278 \\
5 & Manokwari Utara & 40 & 100 & 150 & 182 \\
6 & Manokwari Selatan & 95 & 2 & 235 & 214 \\
7 & Tanah Rubu & 100 & 49.350 & 207 & 207 \\
8 & Masni & 75 & 75 & 152 & 153 \\
9 & Sidey & 371 & 371 & 753 & 488 \\
\hline Jumlahy & 901 & 56.469 & 2.126 & 2.088 \\
\hline
\end{tabular}

Sumber: Data BPS 2020

\section{PEMBAHASAN}

\section{Tahapan Pembuatan Kukis Kelapa}

Pembuatan Tepung Kelapa

Tepung kelapa (desiccated coconut) adalah daging buah kelapa yang dikeringkan, dihaluskan dan diproses dibawah kondisi yang higienis untuk konsumsi manusia (Kumolontang, 2014). Tepung kelapa diperoleh dari proses pengeringan dan penghalusan ampas kelapa. Tahapan pembuatan yang pertama adalah melakukan pengeringan ampas kelapa. Pengeringan bisa dilakukan secara manual dengan menjemur ampas kelapa dibawah sinar matahari hingga kering. Proses sederhana tersebut bisa memakan waktu kurang lebih dua hari, tergantung dengan kondisi cuaca. Selain dengan menjemur ampas kelapa, pengeringan bisa juga dilakukan dengan oven dengan suhu $70^{\circ} \mathrm{C}$ dalam waktu 7 jam.

Setelah proses pengeringan, dilakukan proses pengahalusan ampas kelapa tersebut. Proses penghaluskan bisa dengan cara ditumbuk, digiling maupun diblender. Setelah ampas kelapa dihaluskan, proses selanjutnya adalah pengayakan menggunakan saringan untuk memperoleh tepung kelapa yang halus. Setelah mendapatkan tepung yang halus, sebaiknya tepung tersebut disimpan atau dikemas dalam wadah tertutup. Tepung kelapa sudah bisa digunakan sesuai kebutuhan. 


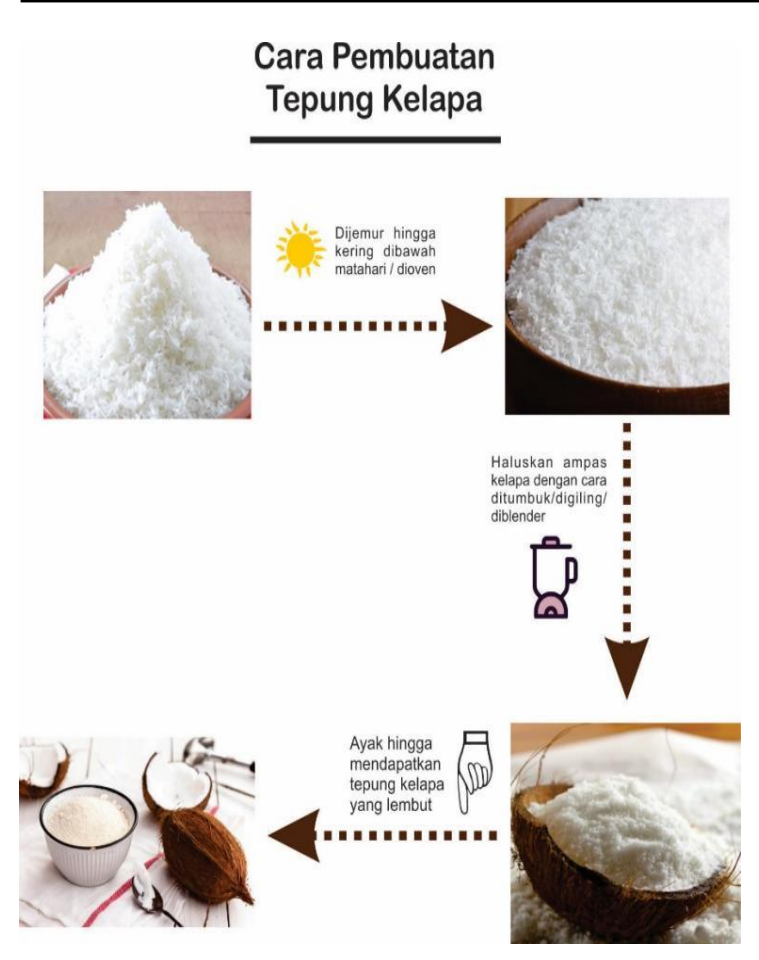

Pengolahan tepung kelapa menjadi kukis diperlukan beberapa bahan-bahan yang harus disiapkan yaitu 300 gram tepung kelapa, 300 gram tepung terigu, 300 gram margarin, 3 butir telur, 300 gram gula halus, 6 sendok makan tepung maezena, 1,5 sendok teh soda kue dan chocochip sesuai selera. Langkah pertama yang dilakukan adalah dengan mencampurkan margarin dengan gula halus, aduk rata lalu tambahkan telur kemudian aduk hingga semuanya tercampur dengan rata. Selanjutnya masukkan tepung kelapa, tepung terigu, tepung maezena dan soda kue kedalam adonan, lalu diaduk hingga semuanya tercampur dengan rata. Setelah itu tambahkan choccocips sesuai selera lalu ambil sedikit demi sedikit adonan untuk dicetak sesuai selera. Kemudian, masukkan kukis yang sudah tercetak ke dalam oven dengan suhu $160^{\circ} \mathrm{C}$ dalam waktu 50 menit hingga kukis matang dan terlihat berubah warna menjadi cokelat keemasan.

\section{Peningkatan Pendapatan Petani Kelapa}

Pendapatan usahatani tergolong masih rendah dan fluktuatif seingga belum dapat mendukung kesejahteraan petani dan keluarganya. Kemampuan petani dalam permodalan dan produk usahatani yang dihasilkan biasanya masih bersifat tradisional, yakni berbentuk kelapa biji atau kopra. Upaya dalam peningkatan produktivitas tanaman dan usaha tani yang masih rendah dapat dengan adopsi teknologi (Masse, 2017).

Pengembangan pengolahan sumber daya alam baik dengan budidaya maupun paska panen memiliki tujuan menambah lapangan kerja dan kesempatan untuk berkembang meningkatkan hasil produksi maupun pendapatan bagi usaha pertanian maupun industri kecil, dan nantinya dapat meningkatkan taraf hidup dan penambahan pendapatan masyarakat (Hartono, 2013). Pemanfaatan limbah ampas kelapa untuk dijadikan olahan makanan yang mempunyai nilai jual ternyata cukup menguntungkan bagi petani kelapa. Limbah kelapa yang umumnya jarang dimanfaatkan bisa menghasilkan pendapatan yang lebih besar daripada pengeluaran untuk biaya produksi.

\section{Biaya Produksi}

Keberhasilan sebuah usaha tidak lepas dari biaya yang dikeluarkan karena biaya merupakan salah satu hal yang sangat menentukan keuntungan. Biaya adalah semua pengeluaran yang dapat dihitung dalam bentuk uang, meliputi biaya yang sudah, sedang maupun yang akan dikeluarkan untuk menghasilkan suatu produksi. Biaya produksi merupakan masukan atau input yang dikalikan 
dengan harga dari proses produksi (Ridha, 2017).

Pengusaha harus ditutut untuk dapat menganalisis teknologi yang digunakan dalam proses produksi dengan menyatukan beberapa faktor produksi lainnya sehingga dapat diperoleh hasil produksi yang efisien dan optimal (Surya, 2012). Biaya produksi adalah sejumlah uang yang dikeluarkan perusahaan untuk memenuhi faktor-faktor produksi dan bahan bahan mentah yang akan digunakan untuk diproduksi menjadi barang-barang dari perusahaan tersebut (Sukirno, 2010). Menurut

Tabel 2. Biaya produksi kukis kelapa
Ruauw (2010) dalam pembuatan suatu produk akan ada biaya yang dikeluarkan untuk produksi dalam suatu periode tertentu. Usaha tani digunakan untuk mencapai produksi dalam bidang pertanian yang akhirnya akan dihitung nilai jual dari suatu produk setelah dihitung dari jumlah biaya output yang telah dikeluarkan dalam satu proses produksi.

Biaya produksi ini dihitung berdasarkan biaya yang dikeluarkan untuk membeli bahanbahan yang digunakan dalam proses pembuatan kukis kelapa.

\begin{tabular}{|c|c|c|c|}
\hline No & & Bahan-bahan & Harga \\
\hline 1 & $300 \mathrm{gr}$ & Tepung Kelapa & 0 \\
\hline 2 & $300 \mathrm{gr}$ & Tepung Terigu Serbaguna & $\mathrm{Rp} \quad 5.000$ \\
\hline 3 & $6 \mathrm{sdm}$ & Tepung Maezena & Rp 10.000 \\
\hline 4 & $1,5 \mathrm{sdt}$ & Baking powder & $\mathrm{Rp} \quad 6.000$ \\
\hline 5 & $300 \mathrm{gr}$ & Gula Halus & $\mathrm{Rp} \quad 5.000$ \\
\hline 6 & 3 butir & Telur & $\mathrm{Rp} 7.500$ \\
\hline 7 & $300 \mathrm{gr}$ & Margarin & Rp 15.000 \\
\hline 8 & 1 pack & Chocochips (pengunaan sesuai selera) & $\operatorname{Rp} 25.000$ \\
\hline
\end{tabular}

Sumber: Data Primer

Kukis kelapa memerlukan beberapa bahan tambahan yang mudah didapatkan di pasar. Bahan yang diperlukan terdiri dari 300 gram tepung kelapa, 300 gram tepung terigu, 6 sendok makan tepung maezena, 1,5 sendok teh baking powder, 300 gram gula halus, 3 butir telur, 300 gram margarin dan 1 pack chocochips atau kismis. Dari takaran bahan yang digunakan tersebut membutuhkan modal Rp 73.500.
Perbandingan tersebut dapat digunakan sebagai pedoman untuk memproduksi kukis kelapa dalam skala rumah tangga maupun skala lebih besar. Dengan demikian petani kelapa dapat mempunyai tambahan penghasilan yang berasal dari pengolahan limbah ampas kelapa. Hal tersebut dinilai dapat memberikan tambahan pendapatan petani kelapa untuk kesejahteraan petani dan keluarganya.

Keuntungan 
Kegiatan usaha tani memiliki tujuan untuk mendapatkan laba, yang biasanya dinilai dari besaran nominal uang yang didapatkan oleh perorangan maupun perusahaan yang bergerak dibidang pertanian baik secara budidaya maupun pasca panen. Nominal harga jual atau nilai suatu produk yang telah dikurangi dari jumlah biaya satu periode siklus produksi yang telah dilakukan oleh pelaku usaha tani baik perorangan maupun perusahaan (Widarti, 2014). Keuntungan merupakan nilai yang diperoleh dari selisih antara pendapatan yang diperoleh dengan biaya produksi yang telah dikeluarkan. Keuntungan yang diperoleh dalam penjualan kukis kelapa diperoleh berdasarkan hasil perhitungan dibawah ini.

Tabel. 3 Keuntungan Penjualan Kukis Kelapa

\begin{tabular}{ccccc}
\hline $\begin{array}{c}\text { Berat bersih kukis } \\
\text { yang diperoleh }\end{array}$ & $\begin{array}{c}\text { Harga jual } \\
\text { kukis /pack }\end{array}$ & $\begin{array}{c}\text { Nilai hasil } \\
\text { penjualan }\end{array}$ & $\begin{array}{c}\text { Biaya } \\
\text { produksi }\end{array}$ & Keuntungan \\
\hline 6 pack (@200g) & $\mathrm{Rp} 60.000$ & $\mathrm{Rp} \mathrm{360.000}$ & $\mathrm{Rp} 73.500$ & $\mathrm{Rp} \mathrm{286.500}$ \\
\hline
\end{tabular}

Sumber: Data Primer

Dengan biaya produksi yang dikeluarkan memperoleh kukis dengan berat bersih $1,2 \mathrm{~kg}$. Kukis tersebut kemudian dikemas dengan berat 200 gram per kemasan. Harga jual kukis per kemasan adalah Rp 60.000, sehingga nilai penjualan sebesar Rp 360.000. Keuntungan yang diperoleh dalam pembuatan kukis dari limbah ampas kelapa tersebut sebesar $\mathrm{Rp}$ 286.500. Akan tetapi, keuntungan yang diperoleh tersebut belum diperhitungkan dengan biaya tenaga kerja. Tenaga kerja yang dibutuhkan dalam pembuatan kukis tersebut cukup 1 orang saja, dengan estimasi waktu pembuatan kurang lebih 3 sampai 4 jam.

\section{KESIMPULAN DAN SARAN}

Tanaman kelapa merupakan tanaman mempunyai beragam manfaat bagi manusia. Hampir semua bagian dari tanaman kelapa bisa dimanfaatkan. Mulai dari batangnya yang dapat dimanfaatkan sebagai bahan bangunan hingga daunnya bisa juga dijadikan sebagai kerajinan tangan. Tidak banyak orang yang mengetahui bahwa ampas kelapa dapat dijadikan sebagai tepung yang mempunyai nilai jual. Tepung kelapa diperoleh dari proses pengeringan dan penghalusan ampas kelapa. Tahapan pembuatan yang pertama adalah melakukan pengeringan ampas kelapa. Pengeringan bisa dilakukan secara manual dengan menjemur ampas kelapa dibawah sinar matahari hingga kering. Proses sederhana tersebut bisa memakan waktu kurang lebih dua hari, tergantung dengan kondisi cuaca. Tepung kelapa bisa dijadikan alternatif untuk membuat olahan makanan salah satunya adalah kukis. Kukis biasanya berbahan dasar tepung terigu, tetapi dengan penambahan tepung kelapa dalam adonannya dapat memberikan rasa yang sedikit berbeda dari kukis pada umumnya. Pemanfaatan limbah ampas kelapa untuk diolah menjadi kukis kelapa mempunyai nilai tambah dari segi ekonomi. Pendapatan petani juga akan meningkat apabila petani diberikan 
pengetahuan mengenai optimalisasi pemanfaatan limbah tersebut. Petani kelapa biasanya hanya menjual kelapa tua kepada pengepul dengan harga yang relatif rendah. Oleh sebab itu, sangat penting untuk memberikan informasi kepada petani mengenai optimalisasi pengolahan kelapa menjadi berbagai macam produk yang mempunyai nilai jual lebih tinggi.

Pemerintah dapat memberikan peluang bagi petani kelapa untuk memperoleh informasi mengenai potensi ampas kelapa untuk meningkatkan pendapatan petani dengan memberikan bimbingan teknis ataupun pelatihan-pelatihan kepada petani. Hal ini diharapkan petani kelapa dapat meningkatkan keterampilannya untuk melakukan pengolahan limbah kelapa tersebut untuk dapat dijadikan sumber penghasilan tambahan sehingga sekaligus dapat meningkatkan kesejahteraan petani.

\section{DAFTAR PUSTAKA}

Abas, D.S. Yanti, S. \& Amelia, M. (2019). Analisis Biaya Dan Pendapatan Usahatani Kelapa Di Desa Tanah Putih Kecamatan Dulupi Kabupaten Boalemo. Jurnal Agrinesia Vol 3 No 3

Alamsyah, A.N. (2005). Virgin Coconut Oil Penakluk Aneka Penyakit. Penerbit Agromedia Pustaka. Jakarta

Badan Pusat Statistik. (2020). Kabupaten Manokwari dalam Angka. Badan Pusat Statistik Kabupaten Manokwari Provinsi Papua Barat

Hartono, N. (2013). Pengaruh Biaya Produksi Terhadap Pendapatan Usaha Pekebunan Kelapa Sawit (Elaeis Guineensis Jacq) Di Desa Bukit Raya Kecamatan Sepaku Kabupaten Penajam Paser Utara. Jurnal Epp. Vol. 10 No.1
Adeloye J.B. \& Halimat, L. (2020). Defatted Coconutflour Improved The Bioactive Components, Dietaryfibre, Antioxidant and Sensory Properties of Nixtamalized Maizeflour. Journal of Agriculture and Food Research Vol 2

Kumolontang, N. (2014). Tepung Kelapa Sebagai Substituen Parsial Dalam Pembuatan White Bread. Jurnal Penelitian Teknologi Industri Vol. 6 No. 2

Kuncoro. (2004). Pendapatan dan Pembangunan Daerah: Reformasi, Perencanaan, Strategi dan Peluang. Jakarta: Erlangga.

Mardiatmoko, M. A. (2018). Produksi Tanaman Kelapa (Cocos Nucifera L). Ambon: Badan Penerbit Fakultas Pertanian Universitas Patimura.

Marwa, J., Anton, S.S., \& Francine, H. (2020). Daya Dukung Bioekologi Hutan dan Lahan di Kabupaten Manokwari, Provinsi Papua Barat. Jurnal Sylva Lestari. Vol. 8 No. 2

Masse, A.A. (2017). Analisis Pendapatan Dan Kelayakan Usahatani Kelapa Dalam Di Desa Kasoloang Kecamatan Bambaira Kabupaten Mamuju Utara Provinsi Sulawesi Barat. E-Jurnal Agrotekbis Vol 5 No 1

Nugraha, I.S. \& Aprizal, A. (2019). FaktorFaktor yang Memengaruhi Tingkat Pendapatan Petani Karet di Desa Sako Suban, Kecamatan Batang Hari Leko, Sumatera Selatan. Jurnal Ilmu Pertanian Indonesia (JIPI) Vol. 24 No 2

Trinidad, A.C. Mallillin, D.H. Valdez, A.S. Loyola, F.C. Askali-Mercado,J.C. Castillo, R.R. Encabo, D.B. Masa, A.S., Maglaya, \& M.T, Chua. (2006). Dietaryfibre from Coconut Flour: A Functional Food, Innovation. Food Sci. Emerg. Technol Vol 7 No 4

Polii, F. (2017). Pengaruh Substitusi Tepung Kelapa Terhadap Kandungan Gizi Dan Sifat Organoleptik Kue Kering. Buletin Palma Volume 18 No. 2

Putri, M.F. (2014). Kandungan Gizi Dan Sifat Fisik Tepung Ampas Kelapa Sebagai Bahan Pangan Sumber Serat. Teknobuga Vol 1 No.1 
Ridha, A. (2017). Analisis Faktor-Faktor Yang Mempengaruhi Pendapatan Petani Di Kecamatan Nurussalam Aceh Timur. Jurnal Samudra Ekonomika, Vol. 1 No. 2

Ruauw, E. (2010). Kajian Pengelolaan Usahatani Kelapa Di Desa Tolombukan Kecamatan Pasan Kabupaten Minahasa tenggara. Jurnal Pengelolaan Vol 7 No 2

Saluki, A. Ratmi, R. (2018). Analisis Pendapatan Petani Kelapa Dalam di Desa Longkoga Barat Kecamatan Bualemo Kabupaten Banggai. Jurnal Agrobiz Vol 1 No 1

Samuelson, Paul. A, Nordhaus, William. (2005). Ilmu Mikro Ekonomi. Penerbit Erlangga. Jakarta

Santoso, M,M,S. Claudivan F,L. Antonia L,R,N. Carlos, H,C,S. Aurelianode, A,R. Marlos, A,B. Isabel, C,S,A. \& Hans, R. (2020). Ecophysiology of The Tall Coconut Growing Under Different Coastal Areas Of Northeastern Brazil. Agricultural Water Management Volume 232

Sukirno, S. (2010). Mikro Ekonomi. PT Raja Grafindo Persada. Jakarta

Supriadi, H. (2008). Strategi Kebijakan Pembangunan Pertanian Di Papua Barat. Pusat Analisis Sosial Ekonomi Dan Kebijakan Pertanian. Vol 6 No. 4

Surya I.G.M.G. (2012). Faktor-Faktor Yang Mempengaruhi Pendapatan Pengerajin Perak Di Desa Celuk Kecamatan Sukawati Kabupaten Gianyar. Jurnal Fakultas Ekonomi Dan Bisnis Universitas Udayana Vol 5 No 2

Widarti S., \& Sunarli L. E. (2014). Analisis Pendapatan Usahatani Kelapa Dalam di Desa Jeruju Besar Kecamatan Sungai Kakap Kabupatan Kubu Raya. Jurnal Ilmiah AgrIBA Vol 1 No 2

Yulvianti, M. Widya Ernayati1, Tarsono, M., \& Alfian R. (2015). Pemanfaatan Ampas Kelapa Sebagai Bahan Baku Tepung Kelapa Tinggi Serat Dengan Metode Freeze Drying. Jurnal Integrasi Proses Vol. 5 No. 2 